phenomenon is still not clear. It has recently been shown that ventilatory response to carbon dioxide in asthmatic patients, measured during recovery from attacks of asthma, plays some part in determining the level of carbon dioxide tension developed during attacks (Rebuck and Read, 1971). As a personality factor has now been shown to correlate with ventilatory response to carbon dioxide in women, it seems likely that, irrespective of the role of personality in the aetiology, precipitation, and continuation of asthmatic attacks, the degree of extraversion in any given asthmatic woman may play a part in the way in which pulmonary ventilation, and hence arterial carbon dioxide levels, are controlled in the presence of airways obstruction.

This work was supported by a donation to the Royal North Shore Hospital of Sydney for respiratory research. We would like to thank Mrs. Elizabeth Saunders for her technical help.
Requests for reprints should be sent to Dr. N. A. Saunders, Thoracic Unit, Royal North Shore Hospital of Sydney, St. Leonards, N.S.W. 2065, Australia.

\section{References}

Burrows, B., Strauss, R. H., and Niden, A. H. (1965). American Review of

Respiratory Diseases, $91,861$.
Clark, T. J. H. (1968). Clinical Science, 34, 559.

Clark, T. J. H., and Cochrane, G. M. (1970). British Medical fournal, 1, 273.

Eysenck, H. J. (1960). The Structure of Human Personality, 2nd edn. London, Methuen.

Eysenck, H. J., and Eysenck, S. B. G. (1964). Manual of the Eysenck Personality Inventory, London, University of London Press.

Freeman, E. H., Feingold, B. F., Schlesinger, K., and Gorman, F. J. (1964) Psychosomatic Medicine, 26, 543.

Goldman, H. I., and Becklake, M. R. (1959). American Review of Tuberculosis and Pulmonary Diseases, 79, 457.

Haywood, C., and Bloete, M. E. (1969). Fournal of Applied Physiology, 27, 32

Read, D. J. C. (1967). Australasian Annals of Medicine, 16, 20.

Rebuck, A. S., and Read, J. (1971). Clinical Science, 41, 13.

\title{
Management of Third Stage of Labour, with Particular Reference to Reduction of Feto-Maternal Transfusion
}

\author{
O. A. LADIPO
}

British Medical fournal, 1972, 1, 721-723

\section{Summary \\ Methods of management of the third stage of labour were compared in $\mathbf{2 0 0}$ cases, noting the effect on feto-maternal transfusion. The incidence of feto-maternal transfusion was found to be $66 \%$ in cases managed in the orthodox manner, compared with $33 \%$ in those in whom free cord bleeding was allowed. The magnitude of transplacental bleeding was also less when bleeding was allowed.}

\section{Introduction}

Feto-maternal transfusion occurs in varying degrees in all pregnancies. However, the rhesus-negative mother carrying a rhesus-positive baby is likely to be affected as a consequence of such a transfusion. Feto-maternal transfusion can occur in the antepartum and intrapartum period, but is much more likely in the latter period (Zipursky et al., 1959; Fraser and Raper, 1962; Sullivan and Jennings, 1966; Woodrow and Finn, 1966). The magnitude of such transfusion varies considerably, and in some cases the quantity is small with no apparent antigenic stimulus, while larger quantities may provoke rhesus-antibody formation.

Little stress has been laid on the management of the third stage of labour with reference to the reduction of transplacental haemorrhage, despite the fact that most of these transfusions occur at this stage. Dunn (1966) and Dunn and Fraser (1966) showed that early cord ligation and the use of oxytocic drugs increase the blood pressure within the placental vasculature during the third stage of labour. He suggested the possibility of increased transplacental transfusion as a result of the rupture of the large placental vessels and enlarged capillaries of the placental villi due to raised intravascular cord pressure.

It was of considerable interest when Terry (1970) showed that by allowing free cord bleeding in the third stage the volume and

\section{Royal Gwent Hospital, Newport, Monmouthshire}

O. A. LADIPO, M.B., CH.B., M.R.C.o.G., Senior House Officer (Present address: Department of Obstetrics, St. David's Hospital, Cardiff) pressure of fetal blood within the placenta may be reduced, with consequent diminution in the volume of feto-maternal transfusion. Free cord bleeding from the placental side was performed immediately the baby was born. However, evidence at present suggests that this method of draining the cord immediately at birth probably leads to a marked reduction in the placental transfusion of the baby (Gunther, 1957; Uscher et al., 1963), which may lead to an increased incidence of respiratory distress syndrome in small babies (Duckman et al., 1953; Bound et al., 1956, 1962; Moss et al., 1963, 1964).

An attempt has been made to compare the effects of three methods of managing the umbilical cord in the third stage on feto-macernal transfusion and on placental transfusion of the baby.

\section{Subjects and Method}

In this investigation only primigravida and gravida-2 rhesusnegative mothers who had an uncomplicated pregnancy, a spontaneous labour, and an unassisted vaginal vertex delivery were studied. Syntometrine, containing $0.5 \mathrm{mg}$ of ergometrine and 5 units of oxytocin, was injected intramuscularly at the time of delivery of the anterior shoulder. The placenta was delivered by Brandt Andrew's method. Thirty minutes after delivery $5 \mathrm{ml}$ of maternal blood was taken and put into a Sequestrene bottle. This was examined for fetal cells by the acid-elution technique of Kleihaur et al. (1957).

The third stage of labour was managed in one of three ways:

Method 1.-One hundred cases were managed in the orthodox manner of clamping the cord, and the placenta was delivered by Brandt Andrew's method.

Method 2.-In 62 cases the cord was clamped $12 \mathrm{~cm}$ from the navel as soon as the baby was born, a single artery forceps being used. This was followed immediately by division of the cord and free drainage from the placental side into a kidney dish. This volume of blood was measured (preplacental transfusion method).

Method 3.-In 38 cases late clamping of the cord was practised. The cord was clamped about $12 \mathrm{~cm}$ from the navel with a single artery forceps only after the cord pulsation ceased. The cord was then divided and free drainage from the placental side into a kilney dish was practised. The blood volume drained was measured (postplacental transfusion method). 


\section{Results}

Degree of Feto-maternal Transfusion.-This is analysed in Table I and the cases are classified as ABO compatibility and incompatibility between mother and fetus. The percentages of cases with transplacental transfusion-that is, positive Kleihaur test-are:

TABLE I-Number of Fetal Cells in Maternal Blood (in 50 L.P.F.) According to ABO Compatibility Between Mother and Fetus

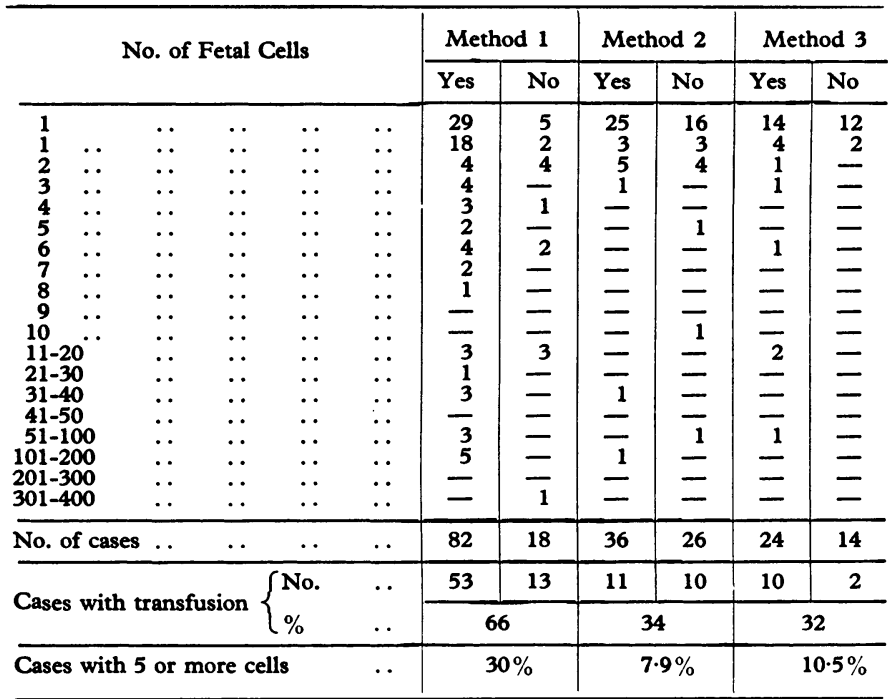

Yes $=$ Mother and fetus $\mathrm{ABO}$ compatible. No = Mother and fetus $\mathrm{ABO}$ incompatible.

method 1, 66; method 2, 34; and method 3, 32. There is no statistical difference between methods 2 and 3, where free cord bleeding was allowed, and both combined give an average of $33 \%$ as against $66 \%$ in method 1 . A fetal cell score of 5 and over after delivery is associated with a high incidence of rhesus immunization six months after delivery ( 1 in 5 cases), while a score under 5 has an incidence of 1 in 20 (Combined Study from Centres in England and Baltimore, 1966). Therefore a score of 5 cells can be regarded as an index of demarcation between the high-risk and low-risk patients. In terms of magnitude of fetomaternal transfusion a score of 5 represents a haemorrhage of about $\mathbf{0 . 2 5} \mathrm{ml}$. Of the patients with evidence of feto-maternal transfusion, the percentage of significant transfusion was greater in those managed by method 1 , the respective figures for methods 1,2 and 3 being 30,7.9, and 10.5. Comparing method 1 with $2 P<0.001$, comparing method 1 with $3 P<0.005$, and comparing method 1 with methods 2 and $3 \mathrm{P}<0.005$.

Mean Fetal Cell Count.-The mean fetal cell count per 50 low-power fields is given in Table II, which shows that the count is higher in method $1,18.7$ cells, compared with 4.5 cells in method 2 and 2.5 cells in method 3 . This is because larger transplacental transfusion occurs in cases managed by the orthodox method. In Woodrow and Donahoe's (1968) series of 2,000 cases there were four patients with over 1,000 cells per 50 low-power fields, and it was estimated that the volume of fetal blood was $40,120,140$, and $170 \mathrm{ml}$ respectively.

TABLE II-Analysis of Results According to Method Used for Third Stage and ABO Compatibility of Mother and Fetus

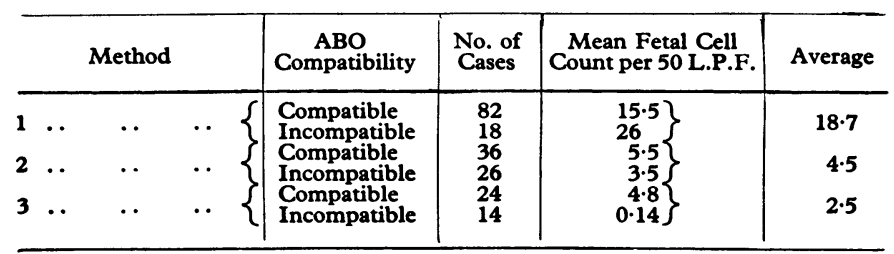

Apgar Score.-The effect of early cord clamping on the Apgar score of the babies was investigated (Table III). Apgar score was recorded one minute after delivery.

TABLE III-Apgar Scores

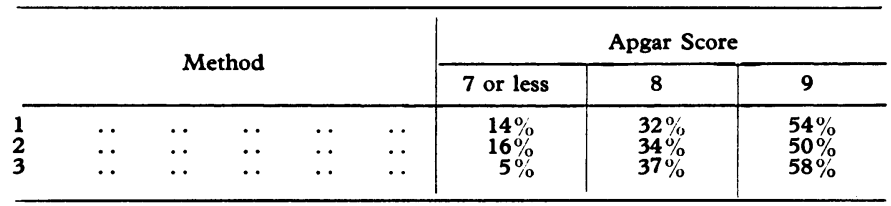

Comparing method 1 with 2 there was no statistical difference. Comparing method 1 with 3 P $<0.05$.

Comparing method 2 with $3 \mathrm{P}<0.05$.

Cord Blood Drained Passively. - The amount of cord blood drained passively in method 2 was $82.7 \mathrm{ml}$ (range of $50-130 \mathrm{ml}$ ) and in method $340.9 \mathrm{ml}$ (range of 5-90 ml), a difference of 41.8 ml. Comparing method 2 with $3 t=9.37, \mathrm{P}<0.001$. Of those with an Apgar score of 7 or less in method $260 \%$ had residual cord blood of above $100 \mathrm{ml}$, while in method 3 all had residual cord blood of less than $90 \mathrm{ml}$.

\section{Discussion}

Since the discovery of the rhesus factor by Levine and Stetson (1939), attempts have been made to overcome the problems of rhesus immunization. The sensitization of rhesus-negative primigravida can be prevented by the administration of passive anti-D immunoglobulin within 36 hours of delivery of a rhesuspositive baby, but failures still occur owing to the large fetomaternal transfusions (Hughes-Jones and Mollison, 1968; de Wit and Borst-Eilers, 1968; Woodrow and Donahoe, 1968).

Since a large number of potentially immunizing transplacental transfusions still occur in the third stage of labour, any procedure which will reduce this will decrease the incidence of these occasional failures. The results suggest that management of the third stage should be given particular attention in non-sensitized rhesus-negative mothers. Allowing free drainage of the cord electively into a dish (method 2) or into the baby (method 3 ) reduced the incidence of significant transplacental transfusion$30 \%$ in method 1 compared with $7.9 \%$ and $10.5 \%$ respectively for methods 2 and 3 ( $P<0.001 ; P<0.005$ respectively). This could well reduce the number of patients in whom anti-D treatment fails.

Late clamping of the cord (method 3) may have an advantage over early clamping and free cord drainage (method 2 ) as it allows greater placental transfusion of the baby. Placental transfusion varies a great deal and is generally accepted as being complete when the cord pulsation has ceased; this produces $20-30 \%$ of the neonate's blood volume (Duckman et al., 1953; Gunther, 1957; Secher and Karlberg, 1962). The mean cord blood drained in method 2 was $41.8 \mathrm{ml}$ greater than that drained in method $3(\mathrm{P}<0.001 ; t=9.37)$. This finding is similar to that of Redmond and Isana (1965).

Duckman et al. (1953), Bound et al. (1962), and Moss et al. $(1963,1964)$ showed a marked reduction in the incidence of respiratory distress syndrome in premature babies who had been allowed placental transfusion. This study shows that delayed clamping of the cord does not adversely affect the Apgar score of the baby at birth. Moss et al. (1964) showed that $75 \%$ of those clamped early had depressed Apgar score at one minute compared with $25 \%$ of those clamped late.

Though the first baby of a rhesus-negative mother is rarely affected, the importance of its survival is obvious. The premature delivery of a rhesus-negative woman's first child may lead to a tragic situation of the baby dying from respiratory distress syndrome or prematurity. Despite the use of anti-D, should the mother become severely sensitized owing to large transplacental transfusion her subsequent pregnancies would be in jeopardy. 
Methods 2 and 3 have considerably reduced the magnitude of feto-maternal transfusion; however, the latter is advocated as evidence at present suggests that placental transfusion reduces the mortality from respiratory distress syndrome.

I thank the consultants at the Royal Gwent Hospital for allowing me to investigate patients under their care and Dr. D. G. Daniel for much helpful guidance. I am also grateful to Mrs. Collins and the labour ward staff for their incessant help.

\section{References}

Bound, J. P., Butler, N. R., and Spector, W. G. (1956). British Medical Fournal, 2, 1260.

Bound, J. P., Harvey, P. W., and Bagshaw, H. B. (1962). Lancet, 1, 1200. Combined Study from Centres in England and Baltimore (1966). British Medical fournal, 2, 907.

Duckman, S., Merk, H., Lehmann, W. X., and Regan, E. (1953). American fournal of Obstetrics and Gynecology, 66, 1214.
uckman, S., Merk, H., Lehmann, W. X., and Rega

Dunn, P. M. (1966). Fournal of Obstetrics and Gynaecology of the British Commonwealth, 73, 747.
Dunn, P. M., and Fraser, I. D. (1966). Fournal of Obstetrics and Gynaecology of the British Commonwealth, 73, 757.

Fraser, I. D., and Raper, A. B. (1962). British Medical fournal, 2, 303.

Gunther, M. (1957). Lancet, 1, 1277.

Hughes-Jones, N. C., and Mollison, P. L. (1968). British Medical fournal, 1,

Kleihauer, E., Braun, H., and Betke, K. (1957). Klinische Wochenschrift, 35, 637.

Levine, P., and Stetson, R. E. (1939). Fournal of the American Medical Association, 113, 126.

Moss, A. J., Duffie, E. D., and Fagan, L. M. (1963). Fournal of the American Medical Association, 184, 48.

Moss, A. J., Emmanouilides, G. C., Adams, F. H., and Chuang, Katok (1964). Pediatrics, 33, 937.

Redmond, A., and Isana, S. (1965). Lancet, 1, 283.

Secher, O., and Karlberg, P. (1962). Lancet, 1, 1203.

Sullivan, J. F., and Jennings, E. R. (1966). American fournal of Clinical Pathology, 46, 36 .

Terry, M. F. (1970). Fournal of Obstetrics and Gynaecology of the British Commonwealth, 77, 129.

Uscher, R., Shephard, M., and Lind, J. (1963). Acta Paediatrica, 52, 497. de Wit, D. C., and Borst-Eilers, E. (1968). British Medical fournal, 4, 139. Woodrow, J. C., and Donahoe, W. T. A. (1968). British Medical fournal, 4,

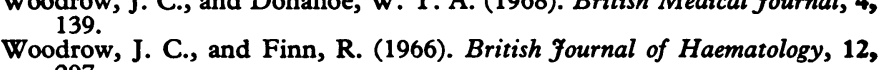
297.

Zipursky, A., Hull, A., White, F. D., and Israëls, L. G. (1959). Lancet, 1, 451.

\title{
Cell-mediated Immunity in Herpesvirus hominis Infections
}

\author{
J. M. A. WILTON, L. IVANYI, T. LEHNER
}

British Medical fournal, 1972, 1, 723-726

\section{Summary}

The cell-mediated and antibody responses to Herpesvirus hominis type 1 were investigated in patients with primary and recurrent herpetic infections. Stimulation of lymphocyte transformation with the virus and the complement fixing antibody titre did not differ significantly between patients and controls. However, macrophage migration inhibition and lymphocyte cytotoxicity were impaired in patients. The defects were specific to $H$. hominis, as Candida oblicans, which was used as an unrelated antigen, failed to show a similar abnormality. These results and preliminary sequential studies suggest that the susceptibility to recurrent herpesvirus infection may be due to an impaired production of macrophage migration inhibition factor and lymphocyte cytotoxicity in the presence of intact lymphocyte sensitization and antibody formation.

\section{Introduction}

Serological evidence of Herpesvirus hominis infection can be found in up to $90 \%$ of adults (Buddingh et al., 1953; Smith et al., 1967; Douglas and Couch, 1970), and clinical or subclinical infection is probably acquired in early childhood. Recurrent infections are common, but as these patients have serum virus neutralizing antibodies (Nagler, 1944; Douglas and Couch, 1970) the latter do not seem to have a protective function. It is possible that cell-mediated immunity might be involved in the protection from recurrent herpetic infections. Indeed, there is

\footnotetext{
Departments of Microbiolology and Oral Immunology and Microbiology, Guy's Hospital Medical and Dental Schools, London SE1 9RT

J. M. A. WILTON, B.D.S., L.D.S. R.C.S., Lecturer in Microbiology
L. IVANYI, DIP.D.S., Research Associate

T. LEHNER, M.D., M.R.C.PATH., Professor of Oral Immunology
}

evidence from cellular immunodeficiency syndromes (Cooper et al., 1968; Fulginati et al., 1968; Glasgow, 1970) and from a variety of virus infections (Blanden, 1970; Zisman et al., 1970) that cell-mediated immunity is an important defence mechanism against viruses. $H$. hominis has not been used in lymphocyte function tests except to stimulate lymphocyte transformation in an investigation of amyloidosis (Lehner et al., 1970).

The present study was undertaken to determine the part played by cell-mediated immunity in both primary and recurrent $H$. hominis infections in adults. The aim was to test the immune competence of lymphocytes to $H$. hominis type 1 by means of the lymphocyte transformation, cytotoxicity, and macrophage migration inhibition tests and to compare these with the complement fixing antibody titres.

\section{Patients and Methods}

Infections with $H$. hominis were diagnosed on clinical, cultural, cytological, and serological evidence, and at the time of the first examination the lesions had been present from one to six days. The series consisted of six patients with primary herpetic stomatitis, seven with recurrent herpes labialis at the time of examination, and six with a definite history of recurrent herpes labialis. As controls, up to 36 normal subjects with no history of recurrent herpetic infections were studied.

A sample of about $50 \mathrm{ml}$ of peripheral blood was obtained from each subject and about $40 \mathrm{ml}$ was placed in a heparinized bottle; the remainder was placed in a dry, sterile bottle, and allowed to coagulate, and the serum was removed. Leucocyterich plasma was obtained from heparinized blood, using dextran sedimentation, and leucocyte cultures were prepared for the lymphocyte transformation test (Ivanyi and Lehner, 1970).

The three tests of lymphocyte function-lymphocyte transformation, lymphocyte cytotoxicity, and macrophage migration inhibition-were performed in parallel on the same specimen of blood. Lymphocyte transformation was carried out with both autologous serum and fetal calf serum as culture supplements, but lymphocyte cytotoxicity and macrophage migration inhibition tests were performed only with fetal calf serum. 